\title{
Research on the Ideological and Political Education of Universities by Multi-dimensional Integration of Transportation
}

\author{
Yuping $\mathrm{Xu}^{1}$ and Zhigang $\mathrm{Wu}^{1, *}$ \\ ${ }^{1}$ School of Transportation Engineering, East China Jiaotong University, Nanchang, Jiangxi 330013, China \\ *Corresponding author.Email: wuzhigang1217@qq.com
}

\begin{abstract}
With the continuous promotion of teaching reform planning in universities, ideological and political education is the core link of ideological work in the new era. As a planning goal during the 14th Five-Year Plan, the strategy of building Chinese strength in transportation is a key task in the new journey of modernization of Chinese transportation industry. As the cornerstone of building Chinese strength in transportation, transportation colleges and universities carry the important task of cultivating talents for the construction of modern transportation networks and are the vanguard of new ideological education in applied universities. Taking transportation universities as a starting point, this paper explores the ways and means of integrating ideological and political education into the construction of professional courses and discipline systems in universities by analysing the development of ideological and political education in applied universities, starting from three aspects of teaching managers, teachers and students, and introducing synergy effects. In order to improve the system mechanism and measures, build a new comprehensive education ecosystem, and realize all-round moral education.
\end{abstract}

Keywords: teaching reform, ideological and political education, professional courses, discipline construction, multidimensional synergy

\section{INTRODUCTION}

General Secretary Xi Jinping pointed out at the Sixth Plenary Session of the 19th Central Committee in 2021 that in order to accelerate to strengthen education, improve the top-level design of ideological and political work, coordinate the integrated construction of ideological and political courses, and promote high-level education opening to the outside world, the construction of ideological and political courses should be promoted in all universities nationwide. We should deepen education reform and innovation, accelerate education evaluation reform in the new era, strengthen the construction of talents in universities, so as to cultivate more strategic scientists, and train dream builders to build the "dream team" of Chinese nation. As the foundation of universities in China, curriculum education is the main way to educate people, and the key way to achieve all-round education in universities is to integrate the education into professional curriculum and discipline system.

As a basic service industry of strategic significance for national economic and social development, the 19th National Congress of the Communist Party of China has elevated the construction of strengthening Chinese transportation to a national strategy. Faced with the strong market potential and broad development prospect of the transportation industry, transportation colleges and universities are urgently required to accelerate the cultivation of applied engineering and technology talents. It is of great practical and strategic significance to deepen the ideological and political education in transportation colleges and universities to promote the sustainable and rapid development of the industry.

The collaborative education of various professional courses and ideological and political education courses has been gradually promoted and popularized in China, but the degree of integration of ideological and political education and various courses and disciplines in universities is not enough [1]. The research on the ideological and political education in Chinese universities is mainly analysed from a single dimension, such as the construction of curriculum system, professional curriculum construction and discipline system development, etc. And the multifaceted integration and synergy of the universities' ideological and political education system established in this paper is not yet common [2]. Ideological and political education in foreign universities is mainly reflected in moral education courses, and relevant studies mostly focus on integrating ethics and morality and other related theories into the education of professional courses, so that the values of students can be cultivated and improved [3]. Therefore, it is urgent to solve the issue of building an ideological and political education system in applied universities from three dimensions: ideological and political curriculum, ideological and 
political professionalism and ideological and political disciplinary. Figure 1 shows the research path of this article.

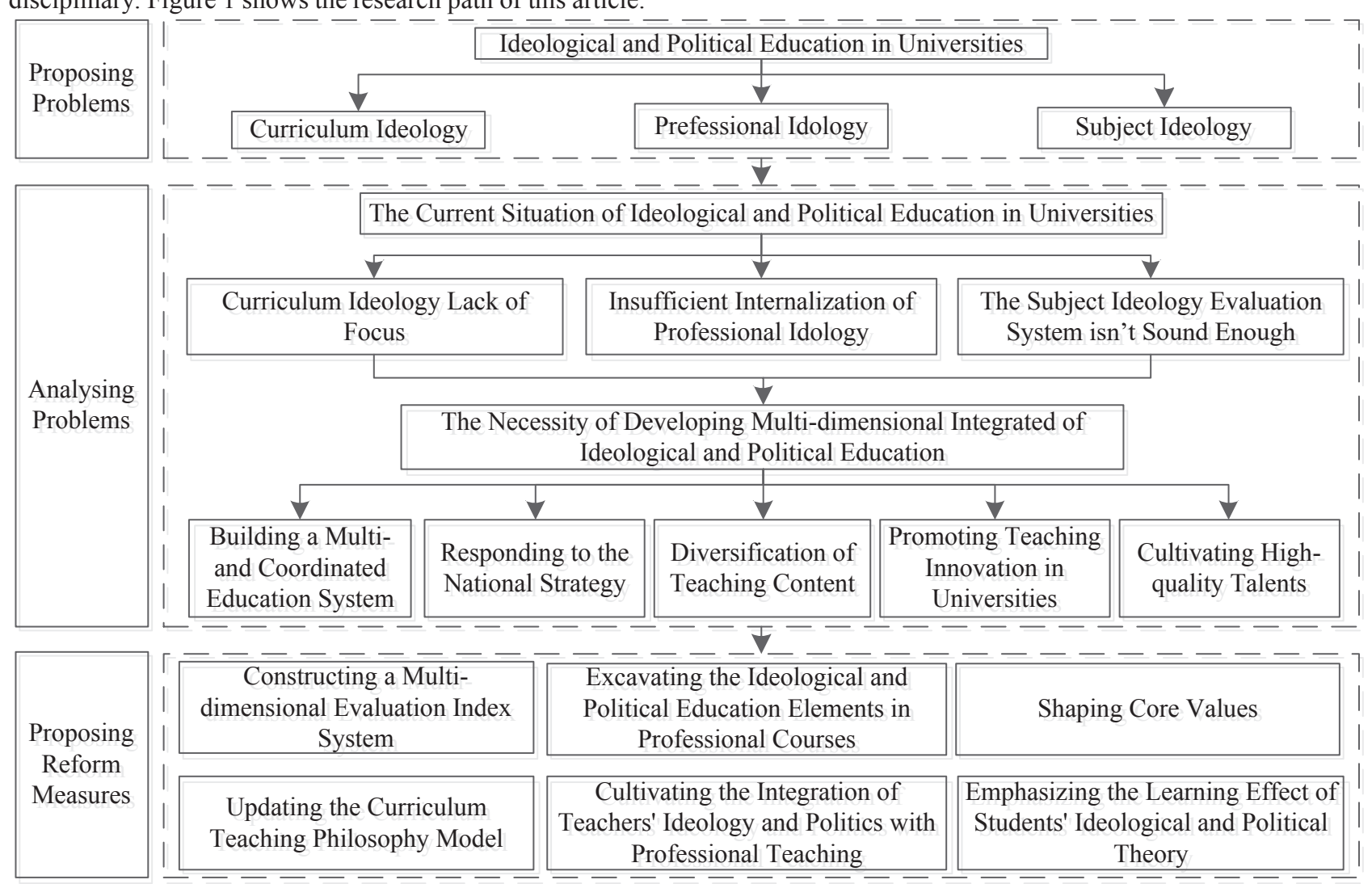

Figure 1. Roadmap of Ideological and Political Education Research in Universities with Multi-dimensional Integration and Power

\section{THE CURRENT SITUATION OF IDEOLOGICAL AND POLITICAL EDUCATION IN UNIVERSITIES}

Although the current transportation colleges and universities actively carry out ideological and political education. However, there're still problems such as insufficient study of professional ideological and political education theory, unsound institutions, unclear managerial responsibilities and misunderstandings.

\subsection{Lacking of Focus in Ideological and Political Curriculum}

The curriculum concept was first proposed by the Shanghai Municipal Government in 2014, and it is the root of the fundamental task of establishing morality for universities. It aims at the formation of leadership values and is the prerequisite for the establishment of multi-dimensional integration and collaboration in universities [4]. By giving full play to the moral education function of the curriculum, the culture contained in the curriculum is transformed into a teaching carrier of socialist core values.
In the current university curriculum system, the separation of ideological education, political education and specialized curriculum education is serious [5]. In the traditional moral education process, teachers pay attention to theory and give less explanation of practical ideological and political knowledge in daily production. Students aren't interested in learning. Professional courses often only teach professional skills, ignore ideological and political literacy, and are mostly limited to mechanical copying of ideological and political theories. The phenomenon of "two skins" between ideological and political courses and professional courses is presented in general.

\subsection{Insufficient Tension between "Ideological and Political Professionalism" and Values}

Political thoughts in professional courses are related to the realization of moral education, and university political and thought education must be integrated into various forms of curriculum practice. The current professional moral education construction needs to emphasize the cultivation of the ideological and political ability of professionals in the professional field [6].

Nowadays, in the curriculum system of applied universities, the integration of ideological and political knowledge and 
professional knowledge often stays on the surface. The teaching of ideological elements in the practical teaching of professional courses mostly stays at the teaching of shallow knowledge, while ignoring the guidance of values. In addition, there is widespread lack of depth in professional ideological and political organization coverage. At the same time, the rights and responsibilities of construction managers are unclear. However, the progress of the times requires a strong professionalism, among which the sense of responsibility and the sense of innovation possessed by socialist values are indispensable.

\subsection{Unsound Evaluation System of "Ideological and Political Disciplinary"}

In 2018, General Secretary Xi Jinping pointed out that the discipline system, teaching system, teaching material system and management system should be designed around moral education. The combination of moral education thought and discipline means that the university establishes a system of disciplines and ideological and political collaboration to promote the effect of moral education. In the process of education, it's necessary to guide students to integrate educational concepts and conduct practical explorations of scientific research [7].

The evaluation system is a vital part of the ideological and political construction of disciplines in universities. However, for a long time, the teaching evaluation of applied universities has frequently focused on the teaching achievements and students' mastery of professional theories and skills, and lacked the assessment of the ideological and political literacy contained in the professional disciplines. In the construction of the subject teaching evaluation system, transportation colleges and universities should improve the comprehensive evaluation system of teacher teaching and student learning effects in ideological and political learning.

\section{THE NEED FOR MULTI- DIMENSIONAL INTEGRATION AND POWER OF IDEOLOGICAL AND POLITICAL EDUCATION IN APPLIED UNIVERSITIES}

As an important base for the training of talents in the new era, universities not only impart professional theoretical knowledge and skills to students, but also shoulder the important task of enhancing students' political knowledge and fair value. As a university's basic mission, ideological and political education plays an important role in fostering personality and civil virtues. Applied universities must rely on existing teaching resources to integrate "curriculum ideological and political", "professional ideological and political" and "disciplinary ideological and political". Promote educational reform and development through the use of multi-dimensional moral education models to achieve effective educational goals.

\subsection{Constructing a New Type of "large-scale Ideological and Political" Pattern of Multi- faceted and Coordinated Education System in Universities}

The construction should be based on disciplines, majors, and courses. The ideological and political education ecosystem is based on schools, universities, disciplines, professional research offices, class teachers and counselors. It's necessary to organically integrate the three major carriers and the six disciplines. In the process of guiding students to carry out scientific research on transportation topics, the fundamental task is to educate people and build morality. We need to build a new type of comprehensive education concept and realize all-round education.

\subsection{Responding to the Strategy of Building Chinese Strength in Transportation and Education}

In the report of the 19th National Congress of the Communist Party of China, General Secretary Xi Jinping proposed the strategy of strengthening the country through transportation. As a national transportation training base for high-level talents, transportation colleges and universities should attach importance to ideological and political education while improving the level of professional ability teaching. In order to build a curriculum system for applied undergraduate applied talents with industry literacy as the core, applied universities should take curriculum ideology and politics as the foothold of discipline and professional construction. So as to make the school rich in ideological and political teaching characteristics.

\subsection{Promoting the Diversified Development of Teaching Contents}

Through the integration of ideological and political education knowledge and traditional teaching models, the promotion of diversified teaching models is promoted. In order to stimulate students' initiative in learning, teachers should adopt a variety of teaching methods based on traditional teaching methods. In the practice teaching link, it's necessary to encourage communication and learning between students based on appropriate teaching methods [8]. So as to help students master the knowledge points and enrich the knowledge points of ideological and political education.

\subsection{Promoting Innovation of Teaching Reform in Universities}

The fundamental task of university education is to foster morality, integrate ideological and political elements into classrooms, majors, and disciplines in the university 
education system, which can promote the improvement of university education and teaching methods, and achieve the effect of traditional education model innovation [9]. Through teaching reform and innovation, teachers of various professional courses can have the political qualities that traditional ideological and political teachers should have. While guiding the formation of students' values, expand the depth and breadth of knowledge learning. Combine the ethical values hidden in the surface of knowledge and internal structure with professional courses in transportation. And explore the ideological quality of knowledge cohesion. Help transportation students further improve their personal qualities and ideals and beliefs [10].

\subsection{Cultivating Dream Builders of the Chinese Dream with High Ideological and Political Awareness and Strong Professional Skills}

All applied universities should actively respond to various planning tasks. The goal is to build first-class disciplines, first-class majors and first-class courses [11]. Based on professional courses, grasp the "three-in-one" goal of university talent value construction, knowledge transfer, and ability training. Cultivate the enthusiasm of professional course teachers for political education and ideological and political development. Promote the comprehensive literacy development of transfer students. In the new era and new journey, cultivate talents with high-level political consciousness and idealism, and the construction of highlevel professional fields in the country.

\section{MEASURES FOR REFORMING IDEOLOGICAL AND POLITICAL EDUCATION IN APPLIED UNIVERSITIES}

Thinking and policy education is at the heart of modern university moral education. The education system of transportation-related universities integrates ideological and political theory into the construction of disciplines, majors, and courses can cultivate more high-quality talents who incorporate ideological and moral qualities and professional skills [12]. Applied universities need to accelerate the construction of a new ideological and political education system, promote innovation and complete the task of comprehensive coverage of the "three holistic education".

\subsection{Constructing a Multi-dimensional Evaluation Index System for Ideological and Political Education in Universities}

Ideological and political education in applied universities should be explored from the three dimensions of courses, majors, and disciplines. Construct a system with discipline system, professional teaching and curriculum guidance as the carrier, and schools, universities, professional teaching and research offices, class teachers, and counselors as the main body. Based on the correct value orientation and multidimensional evaluation index system, establish an efficient interactive feedback mechanism to promote the construction of a benign ecological construction and optimization path for ideological and political education in colleges and universities.

\subsection{Fully Exploiting the Elements of Ideological and Political Education in Professional Courses}

Applied universities should fully tap the ideological and political education resources in professional courses. When making professional courseware and teaching cases, ideological and political education resources such as news and current affairs hotspots, craftsmanship spirit, and value orientation of professional disciplines should be organically combined with professional curriculum content [13]. By improving the degree of coupling between various courses and the operational goals, the students' research craftsmanship and professionalism will be cultivated.

\subsection{Focusing on Shaping the Values of Teachers and Students}

All colleges and universities should rely on ideological and political education to focus on cultivating socialist builders and successors with a firm political stand to realize their own value. It is necessary to take science and engineering teachers and students as the center, infiltrate family and national feelings, and shape the correct world outlook, outlook on life and values [14]. While imparting and learning professional and technical capabilities, the sense of social responsibility should be enhanced. In order to find a new way to improve the pertinence and effectiveness of college students' ideological and political education. Eventually shape talents who can undertake the great cause of national rejuvenation.

\subsection{Updating the Conceptual Model of Course Teaching}

With the rapid development of the information age, new teaching models using mobile Internet technology and artificial intelligence technology have entered people's field of vision [15]. Compared with the traditional teaching mode, the teaching mode that incorporates new technology can stimulate students' interest in autonomous learning. Universities should actively promote new technology and methods in the course of teaching, and integrate ideological and political education into high-quality online education platforms to the greatest extent. 


\subsection{Cultivating the Integration of Teachers' Ideology and Politics with Professional Teaching}

The teaching of professional courses is closely related to the teaching ability of teachers. Teachers, as direct participants in the education and morality of colleges and universities, should play a leading role in it. On the road to the reform of ideological and political education in colleges and universities, it is necessary to pay attention to the cultivation of teachers' ideological and political elements. At the same time, professional knowledge should be organically integrated in classroom moral education. It is necessary to pay attention to the teaching ability of teachers to integrate professional subject knowledge and ideological and political knowledge, so as to improve the quality of course teaching.

\subsection{Emphasizing the Learning Effect of Students' Ideological and Political Theory}

The evaluation of students' learning effects is sufficient to reflect the quality of university education and moral education. The fundamental purpose of establishing classroom moral education, professional moral education, and subject moral education is to cultivate more professional scientific and technological talents with higher political literacy for the society in applied universities. Through the assessment of students' ideological and political theory study and practical application ability, it can help universities to establish an effective teaching mode.

\section{CONCLUSION}

On the road to struggle in the new era, colleges and universities should actively respond to the strategy of building a strong country through transportation and education. Through the practical research of the subject, the current situation of insufficient ideological and political strength in the university curriculum in our country can be improved. So as to optimize the teaching and teaching mode of transportation professional courses. Construct a threedimensional college ideological and political education system integrating "curriculum ideological and political", "professional ideological and political", and "disciplinary ideological and political". And promote the formation of a new model of "big ideological politics" collaborative education to improve students' ideological and political level. Through the innovative education evaluation index system, based on transportation colleges and universities, colleges and universities will create a learning environment that integrates education and moral education. Various functional departments organically integrate the ideological and political elements of professional courses by digging deeply into the ideological and political elements of professional fields. By focusing on the cultivation of ideological and political education for teachers and students, colleges and universities can cultivate more high-level scientific and technological talents with a high degree of ideological awareness for the society, and realize all-round moral education.

\section{ACKNOWLEDGMENT}

This research was financially supported by the Educational science planning project of Jiangxi Province Project, "Research on ideological and political education in transportation colleges and universities with a threedimensional force of curriculum ideology, professional ideology and subject ideology and politics".

\section{REFERENCES}

[1]F. Zhu, "Clarification of the value and choice of the way of ideological politics in college curriculum" [J]. Ideological and theoretical education, 2019(08):6772.DOI:10.16075/j.cnki.cn. (In Chinese)

[2]Y.D. Gao, A.D. Zong, "From ideological and Political Curriculum to Curriculum Ideological and Political: Constructing the curriculum system of ideological and political education in colleges and universities from a strategic height" $[\mathrm{J}]$. China Higher Education, 2017(01):43-46. (In Chinese)

[3]Bandini J, Mitchell C, Epstein-Peterson Z D, et al. Student and faculty reflections of the hidden curriculum: How does the hidden curriculum shape students' medical training and professionalization?[J]. American Journal of Hospice and Palliative Medicine $\AA$, 2017, 34(1):57-63.

[4]X.J. Wang, Y. Shi, "The connotation, characteristics, difficulties and countermeasures of ideological politics in the new era" $[\mathrm{J}]$. Journal of Xinjiang Normal University (Philosophy and Social Sciences Edition), 2020, 41(02):50-58.DOI:10.14100/j.cnki.651039/g4.20191125.001. (In Chinese)

[5]Y.B. Li, "The Problem of Tension in the Evaluation of Professional Ideological and Political Effects" [J]. Beijing Education (Higher education), 2021(06):10-13. (In Chinese)

[6]S.L. Zhao, J.C. Wu, Z. Zhang, L.Z. Peng, "Exploration and Analysis of the Construction and Approaches of the Ideological and Political Mixed System of Mechanical Majors"[J]. Mechanical design and manufacturing, 2021(07):101-

104.DOI:10.19356/j.cnki.1001-3997.2021.07.024. (In Chinese)

[7]R.X. Bai, J.T. Yang, G.L. Xue, R.J. Zhao, “On the Innovation of Ideological and Political Education of 
Disciplines in Higher Learning Institutions from the Perspective of Cultivating Virtue and Morality in the New Era" [J]. Journal of Northwest University for Nationalities(Philosophy and Social Science), 2021(03):95-100. (In Chinese)

[8]Adamson S R. Subtle messages: An examination of diversity in the illustrations of secondary level one French textbooks[M]. University of Arkansas, 2013.

[9]Y.H. He, "Exploration on the Essential Connotation and Realization Path of "Curriculum Ideological and Political" [J]. Journal of Ideological and Theoretical Education, 2019(10):130-

134.DOI:10.16580/j.sxlljydk.2019.10.026. (In Chinese)

[10]Egan, K. Learning in Depth: A Simple Innovation That can Transform Schooling[M]. London Ontario: The Althouse Press, 2010:148-149.

[11]L.T. Li, "Integrate ideological and political work into the education of journalism and communication"
[J]. Chinese Higher Education, 2019(18):41-43. (In Chinese)

[12]J.T. Yu, W.Q. Wang, Y.Q. Xu, "The logic and key points of professional teachers' Practice of "Curriculum Thinking and Politics" -- Taking science and engineering courses as an example" [J]. School Party building and ideological education, 2018(01):64-66. (In Chinese)

[13]W. Shi, "On the key points and effective implementation of collaborative education by "curriculum ideology and politics"'[J]. Academic Forum, 2018, 41(04):168-173. (In Chinese)

[14]J. Xu, "Some thoughts on the integration of professional education and ideological and political education" [J]. School Party building and ideological education, 2021(06):49-50. (In Chinese)

[15]Y. Gao, "Key problems and solutions of curriculum ideological and political construction" [J]. Chinese Higher Education, 2017(Z3):11-14. (In Chinese) 